\title{
The Application of Communicative Approach in English Teaching
}

\author{
Hu Shen, Gong Wei \\ Art and Science department, Chengdu College of UESCT, Chengdu, Sichuan, 610000, China
}

Keywords: Communicative approach; English teaching; current situation

\begin{abstract}
As a new teaching method, communicative teaching method is more and more valued and respected by educators. The communicative teaching method takes students as its core and focuses on developing students' abilities. The application of communicative approach in teaching has its advantages and disadvantages. This paper probes into the advantages and disadvantages of communicative approach in English teaching, and puts forward some suggestions on how to use it flexibly according to the actual situation in China.
\end{abstract}

Communicative Language Teaching (CLT) is the English name of Communicative Language Teaching (CLT). Communicative teaching method originated in the 1970s, and has undergone different stages of development. In the initial stage of the development of communicative teaching method, it focuses on seeking teaching syllabus and teaching methods that can improve students' communicative competence. Later, its focus gradually developed to focus on learners' communicative needs. The core content of communicative teaching method is communicative competence, that is, the ability to use the language to communicate effectively with different objects in different situations. In the classroom, the implementation of communicative teaching method is embodied in taking students as the core of classroom teaching.

\section{The present situation of English teaching in china}

On the whole, English teaching in China has made great achievements since the reform and opening up. Whether it is in the number of English talents or in the quality of English talents training, there has been a great improvement over the past. However, due to many reasons, there are still some problems in the specifications, objectives and methods of English teaching in China.

First of all, the training of English talents lacks applicability. As a language, the main direction of English teaching should be application. However, in the process of English teaching in some schools in China, due to the influence of the whole teaching environment, the goal of English teaching still remains in the examination-oriented stage. This leads to the fact that students can not express and communicate fluently in English even though they have accepted English learning for a certain period of time. This is why so-called "dumb English" exists. Therefore, in the process of future English teaching and development, how to emphasize the application of English teaching is the main foothold of the reform.

Secondly, the English teaching environment needs to be optimized. English teaching needs not 
only systematic improvement of teaching objectives, but also advantageous teaching environment to continuously promote the development of the whole teaching. At present, China's teaching environment has made some progress, but it still can not meet the needs of English learners, especially in the hardware environment of English learning, some areas are still relatively backward, students' English level can not be effectively improved in the current teaching environment. In addition, there are some shortcomings in the teaching software environment, including the teaching methods, teaching resources and so on, which students need. All these need to be remedied in the future English teaching reform.

Finally, the teaching staff needs to be improved. In the whole process of English teaching and upgrading, English teachers play an extremely important role. On the whole, English teachers in China. The academic level has reached the standard, but there is still a lot of room for improvement in specific teaching methods and teaching practice. Therefore, how to strengthen English teachers is the main direction of English teaching in the future.

In the application of communicative approach, the following principles should be followed:First, communicative. In the process of implementing communicative teaching method, the design of relevant teaching links and the arrangement of relevant teaching activities should be improved and perfected from the aspect of communication. One of the main starting points of communication is the students' language application needs. With the help of the optimization of the corresponding teaching environment, the comprehensive application level of English learners can be effectively improved. Secondly, interaction. From a certain point of view, communicative teaching method is also a kind of interactive teaching method. In the process of interaction, students will not only consolidate their original knowledge, but also improve their communication and communication skills. Therefore, focusing on interaction is also a major goal of communicative teaching method in the specific application process. Finally, development. In the application process of communicative teaching method, it is necessary to adjust according to students' learning needs and changes in learning content, and constantly optimize the existing solutions so as to better promote students' communication ability. In a word, in order to better realize the teaching function of communicative teaching method, we should constantly improve the corresponding level from the aspects of development, communication and interaction in the daily teaching process. Only in this way can communicative teaching approach maximize its value and significance in promoting teaching.

\section{Current situation of research and application of Communicative Approach}

At present, on the whole, China has made remarkable achievements in the field of English teaching and learning. With the development and application of a large number of advanced western teaching methods in English teaching, our English teaching has also been greatly developed in terms of ideas and concepts. But on the whole, there are still some shortcomings in the application of communicative teaching method in China.

\subsection{The research on communicative approach is not deep enough}

The communicative teaching method needs not only to be studied at the formal level, but also to be studied in many aspects, such as the theoretical basis of the method, the practical environment of the method and the application principles of the method. At present, there are superficial and superficial phenomena in the study of communicative teaching method in China. This is not only not conducive to the application of communicative approach as an English teaching method, but also to the improvement of the whole English teaching. As shown in Table 1: 
Table 1. Organizational Forms of Classroom Communication Activities

\begin{tabular}{|c|c|c|c|c|}
\hline & $\begin{array}{c}\text { Activity } \\
\text { organization form }\end{array}$ & $\begin{array}{c}\text { Activity } \\
\text { times }\end{array}$ & $\begin{array}{c}\text { Percentage of total } \\
\text { activities }\end{array}$ \\
\cline { 2 - 5 } $\begin{array}{c}\text { Interaction } \\
\text { between teachers } \\
\text { and } \\
\text { students(62.45\%) }\end{array}$ & $\begin{array}{c}\text { Teachers' Question } \\
\text { and Students' } \\
\text { Answer Activities }\end{array}$ & $\begin{array}{c}\text { Teachers Ask Individual } \\
\text { Students Answer }\end{array}$ & 129 & $35.34 \%$ \\
\cline { 2 - 5 } & $\begin{array}{c}\text { Teachers Ask and } \\
\text { Answer to the Class } \\
\text { Student Question } \\
\text { and Teacher }\end{array}$ & $\begin{array}{c}\text { Individual Students Ask } \\
\text { Teachers Answer }\end{array}$ & 28 & $17.8 \%$ \\
\cline { 3 - 5 } & $\begin{array}{c}\text { The whole class asks } \\
\text { and answers the teacher }\end{array}$ & 6 & $7.67 \%$ \\
\hline
\end{tabular}

\subsection{The communicative approach lacks practical guidance}

In the process of applying communicative teaching method, it is a goal of English teaching to optimize teaching effect effectively from practice. At present, there are still some deficiencies in the application of communicative teaching method in China, especially in the scientific, theoretical and feasible aspects of the method, which need to be improved systematically. Therefore, relying on the current situation of English teaching methods, how to explore the future improvement of communicative teaching method is also a direction of current English teaching.

\subsection{The application of communicative teaching method needs to be innovated}

With the environment and times putting forward higher requirements for English learners, relevant English teaching methods should keep pace with the times. At present, the application and innovation of communicative teaching method is relatively backward. It is difficult to follow up the concept and implementation in the first time, which affects the overall English teaching effect.

In a word, there is still much room for improvement in the research and application of communicative approach in China. Therefore, how to deepen the research system of communicative approach with the help of the current teaching environment in China is a major issue in English teaching in the future.

\section{The Feasibility and Advantage of Communicative Approach in English Teaching}

Language is a tool of communication. The ultimate goal of language learning is to meet the needs of communication, not to practice the language itself. The communicative approach emphasizes the ability of mastering language knowledge in application, combining learning with the application of real life, and gradually transforming language knowledge into practical application. Students can improve their listening, speaking, reading and writing abilities through interaction.

3.1 The communicative approach teaching method is student-centered, which helps to improve students' learning enthusiasm and stimulate students' creativity

The communicative approach abandons the drawbacks of teacher-centered traditional teaching methods, and arranges teaching contents according to students' actual life and communicative needs. At the same time, communicative teaching method pays attention to students' participation, often 
through lively teaching methods such as group discussion and role-playing. It not only enriches the content of teaching, but also improves the enthusiasm and enthusiasm of students to participate in learning.

\subsection{Communicative Approach emphasizes the fluency and feasibility of language use, provides more opportunities for students to speak, and helps to improve students' self-confidence}

The communicative approach emphasizes the fluency of language use, regards mistakes made by students in the process of language learning as natural phenomena, encourages students to open their mouths, and trains students to use language in simulated environments. It helps to improve students' flexibility and adaptability in using language and their self-confidence.

3.3 The communicative teaching method has a wide range of teaching contents, various teaching methods and broadens students' horizons

The communicative teaching method is different from the traditional teaching method, which is limited to textbook knowledge. Teachers can expand knowledge beyond books in time according to students' level of understanding and needs, and use rich and colorful teaching methods (such as counseling books, TV, movies, multimedia, pictures, etc.). Not only stimulate students' interest in learning, but also broaden their horizons.

4. Problems that should be paid attention to in the application of communicative teaching method

4.1 Communicative teaching method puts forward higher requirements for teachers' quality and teaching ability

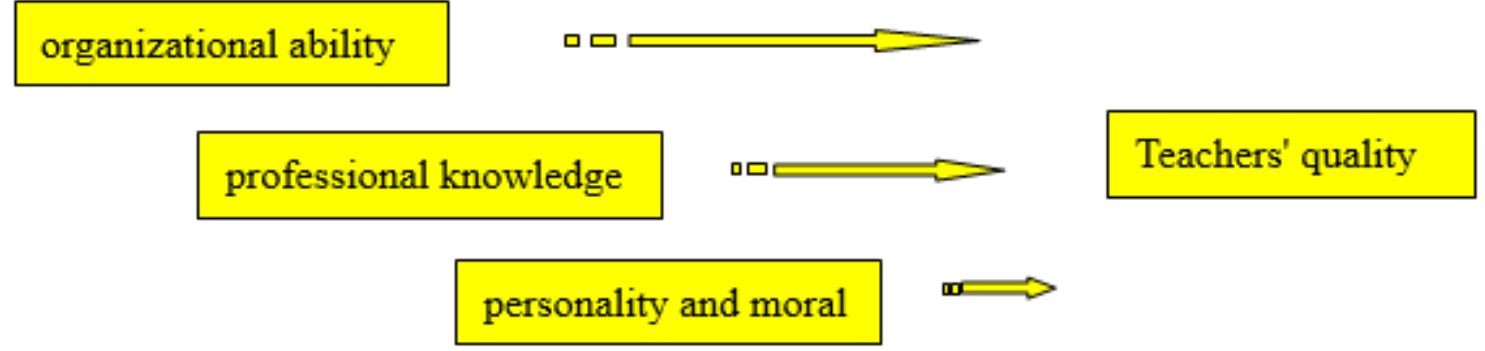

Figure 1 .Teachers' quality

Teachers' quality includes organizational ability, professional knowledge, personality and moral character. The quality of teachers affects the teaching methods and effects. The communicative approach requires teachers not only to teach knowledge well, but also to design teaching, organize learning and guide learning. As communicative teaching method is not limited to the teaching of book knowledge, it requires teachers to spend a lot of time and energy to make adequate preparations before class in order to cope with problems that may arise in the classroom at any time. At present, the teaching staff of our country is uneven, many teachers lack certain professional knowledge and experience, but also lack certain intercultural communication ability, and can not master the essence of communicative teaching method skillfully, which hinders the effective application of communicative teaching method. 


\subsection{The effectiveness of the application of communicative teaching method is influenced by students' own qualities}

Whether the communicative teaching method can be applied effectively or not is influenced by students' own qualities. The communicative teaching method takes students as the core, and students are the main body of teaching activities. Because of the differences of students' educational background, intelligence level and language foundation, the effectiveness of communicative teaching method will be affected.

\section{Conclusion}

As a new teaching method, communicative teaching method has advantages that traditional teaching method can not achieve. It focuses on cultivating students' communicative competence and emphasizes that students are the core of learning. However, as one of many teaching methods, communicative teaching method is not the only effective teaching method, and its realization mode is also varied. When implementing communicative teaching method, we should use it flexibly according to the actual situation of students and the existing educational and teaching facilities to achieve the best results.

\section{References}

[1] Li Ying. Reflections on the Communicative Approach to English Language Teaching [J]. Journal of Xiangtan Normal University (Social Science Edition), 2009 (1).

[2] Sun Wei. How to Deal with the Challenge of Communicative Approach [J]. Style of Science and Technology, 2009 (23).

[3] Shao Dan. Problems of Communicative Approach in Practical Teaching [J]. Anhui Literature (Half Month), 2008

(5).

[4] Li Mei. Application of Communicative Approach in English Grammar Teaching [English] [J]. Science and Technology Information (Science Teaching and Research), 2008 (5).

[5] Shao Lijun, Chen Cuifeng, Chen Xiaofeng, Yan Qiwen. Communicative Approach Application in College English Teaching [J]. Journal of China Environmental Management Cadre College, 2008 (1). 